\title{
Hydrological process monitoring for springshed management in the Indian Himalayan region: field observatory and reference database
}

\author{
Bhargabnanda Dass ${ }^{1}$, Sumit Sen ${ }^{1, *}$, Anita Sharma ${ }^{2}$, Sana Hussain ${ }^{2}$, Nitin Rana ${ }^{2}$ \\ and Debashish Sen ${ }^{2}$ \\ ${ }^{1}$ Indian Institute of Technology Roorkee, Roorkee 247667 , India
${ }^{2}$ People's Science Institute, Dehradun 248001 , India
}

The Indian Himalayan Region (IHR) has experienced accelerated changes in climatic seasonality and land use-land cover. Researchers envision understanding the process controls of water fluxes and their hydrogeological and ecological implications but scarce in si$t u$ data in the IHR hinders scientific research. Our work discusses an integrative technique for springshed monitoring for insights into hydrological processes and understanding integrated measurement strategies. Initial emphasis was on instrumentation and data collection from two headwater watersheds, instrumented with advanced field-based monitoring platforms in Pauri-Garhwal and Almora districts of Uttarakhand. We describe the observatory setup and discuss the pilot sites' general characteristics followed by the monitoring concept, infrastructure and initial datasets of the pilot sites. The social dimension of the spring water use and governance is also analysed in brief. Such a springshed management approach is the way forward for water security in the IHR.

Keywords: Automatic weather station, evapotranspiration, hydrological observatory, Montane ecosystem, springshed management.

\section{Introduction}

HYDROLOGIC responses in mountainous regions regulate water availability, biochemistry, vegetation distribution, and impact regional climate. Improved information about such regions' controlling processes leads to a clearer understanding of the earth's water, energy and ecological fluxes ${ }^{1}$. A primary societal motivation for better hydrological information is for making better-informed decisions in water resources management in mountain systems where the allocation of water in such a supplyconstrained system is dependent on decision systems ${ }^{2}$. Water security as defined by UNESCO's International

*For correspondence. (e-mail: ssenhfhy@iitr.ac.in)

Hydrological Programme's (IHP) Strategic Plan of the Eighth Phase is 'the capacity of a population to safeguard sustainable access to adequate quantities of acceptable quality water for sustaining livelihoods, human well-being, and socio-economic development, for ensuring protection against water-borne pollution and water-related disasters, and for preserving ecosystems in a climate of peace and political stability.' But an increase in population and other developmental activities have increased the water demand and threatened the water security in the Indian Himalayas.

Development, historically, has always neglected the dependency of human well-being on the products and services provided to us by nature. The current situation calls for a paradigm shift in adequately treating our water resources, for water security. Even the 2015 U.N. development agenda promotes the integration of all water and water-dependent sectors to value and manage hydrological ecosystems for water security planning. Building resilience to stresses related to water sectors requires both policy and infrastructure. However, implementing these measures needs reliable assessment of anthropogenic disturbances exerted on hydrological ecosystems. Considering the growing water scarcity trend in the Indian Himalayan Region (IHR), there is an increasing need to understand the hydrology of Himalayan head-water watersheds. Despite the importance of the mountain systems for regional hydrology and water supplies, the processes controlling water fluxes are not well understood; we even poorly understand hydrologic responses connected to the region's geology and ecology. Above all, the lack of dedicated observatories and information systems hamper improvements of the hydrologic dataset. The water budget, which primarily expresses the water input, output and storage, is fundamental to this understanding. Scenario-based projections can be derived from complex models, but a trade-off between model efficiency and practical performance is required. Such predictions largely depend on continuous and high-quality hydrological data. A continuous set of data, unlike discrete data, is 
exact and accurate. It helps in better understanding and interpretation of the hydrological fluxes. Hydrometeorological variables need systematic and state-of-the-art measurement and monitoring techniques and dataprocessing tools. This article presents an overview of the instrumentation of pilot springshed observatories and research opportunities in these springsheds. We also discuss the observed variables and how their interlinkages impact hydrologic responses.

\section{Literature review}

Hydrologic responses in mountain ecosystems influence water availability, land-use patterns, biogeochemical cycling and contaminant transport, and contribute to climatic variations globally. Dedicated research in understanding hydrologic responses is a prerequisite to managing the stressed water resources and establishing security $^{1}$. Informed decision-making towards water resources management pertaining to water allocation, flood mitigation, water demands, and environmental flows needs robust data procuring and monitoring facilities ${ }^{2}$. Montane ecosystems are cardinal to carbon sequestration, biogeochemical processes, and partitioning between water and energy fluxes, which are also highly sensitive to hydrologic variables over space and time like precipitation, run-off, evapotranspiration and subsurface flows ${ }^{3}$. Therefore, a holistic process of understanding and highquality reliable data from advanced field-observation techniques are necessary to predict hydrological processes in montane ecosystems as a result of climate change. Extensive scientific work on Himalayan springs using dedicated monitoring sites for recession curve and flow-duration curve analysis deduced a minimum characteristic value of spring flow rate ${ }^{4}$. Such results are useful for planning springshed management activities leading to enhanced spring discharge/base flows, even during the lean season. Other springshed treatment practices as climate variability bear its effect on the partitioning of precipitation into run-off, infiltration, recharge, and evapotranspiration. Temporally resolved field observations on precipitation intensity and its ecological controls are necessary, but their variations along altitudinal gradients must also be considered. Altitudinal variations were discussed in a study of spring systems in the Lesser Himalaya, which analysed 10 recession events for two continuous years of discharge data to define a discharge decay function of high hydrological significance ${ }^{5}$.

\section{Study area, field instrumentation and data collection}

\section{Haraita watershed, Pauri}

Pauri Garhwal district in Uttarakhand encompassing an area of $5230 \mathrm{~km}^{2}$ located at lat. $29^{\circ} 45^{\prime} \mathrm{N}$ to $30^{\circ} 15^{\prime} \mathrm{N}$ and long. $78^{\circ} 24^{\prime} \mathrm{E}$ to $79^{\circ} 23^{\prime} \mathrm{E}$. Nayar river drains this district, which is a major tributary of the Alaknanda. Climatic condition ranges from sub-temperate to temperate with a maximum and minimum of $25^{\circ} \mathrm{C}$ and $1.3^{\circ} \mathrm{C}$ respectively. The average annual rainfall is $2180 \mathrm{~mm}$. Dasmeri watershed located in Dwarikhal block of Pauri Garhwal district has an area of 610 ha (Figure 1). The local communities, including schools in the villages of Dasmeri, Pali, Bamoli, Kyar and Must of this watershed primarily rely on spring water for drinking and domestic purposes. The spring discharge ranges between 1 and 2.3 litres per minute (LPM) during the lean season, while tap-water supply is also available but is irregular. The villagers have to depend upon springs, especially during the lean season. Geologically, this watershed is mainly dominated by quartzite in the upper part, phyllite in the middle, and slate in the lower part (Figure 2). Instrumentation has been done on the three springs in Dasmeri village namely Nauli Dhara (PS1), Bichola Pani (PS2) and Jethuna Tok (PS3) (Table 1).

\section{Shiv Gadera watershed, Almora}

Almora district is situated in the Kumaon region of Uttarakhand at $29^{\circ} 35^{\prime} \mathrm{N}-29^{\circ} 60^{\prime} \mathrm{N}$ lat. and $79^{\circ} 39^{\prime} \mathrm{E}-79^{\circ} 66^{\prime} \mathrm{E}$ long. on a ridge shaped like a saddle that partitions the watersheds of rivers Kosi and Suyal. The total geographical area is $3697.2 \mathrm{~km}^{2}$, of which $1309.4 \mathrm{~km}^{2}$ is under forests. The average elevation is $1646 \mathrm{~m}$ amsl $(5400 \mathrm{ft})$. Temperature ranges from $28^{\circ} \mathrm{C}$ to $-5^{\circ} \mathrm{C}$, with an annual average rainfall of $960.6 \mathrm{~mm}$. The selected watershed, Shiv Gadhera, is located in the Taluka block of Almora district (Figure 3). It has an area of 176 ha. The pilot villages are Nag Kaurali and Salonj; instrumentation has been done on a spring in the former village (Table 2). Nag Kaurali has three hamlets namely Nag Hanwal, Nag Joshi and Kaurali. Geologically, the area is characteristic of fractured quartzite types of rocks (Figure 4).

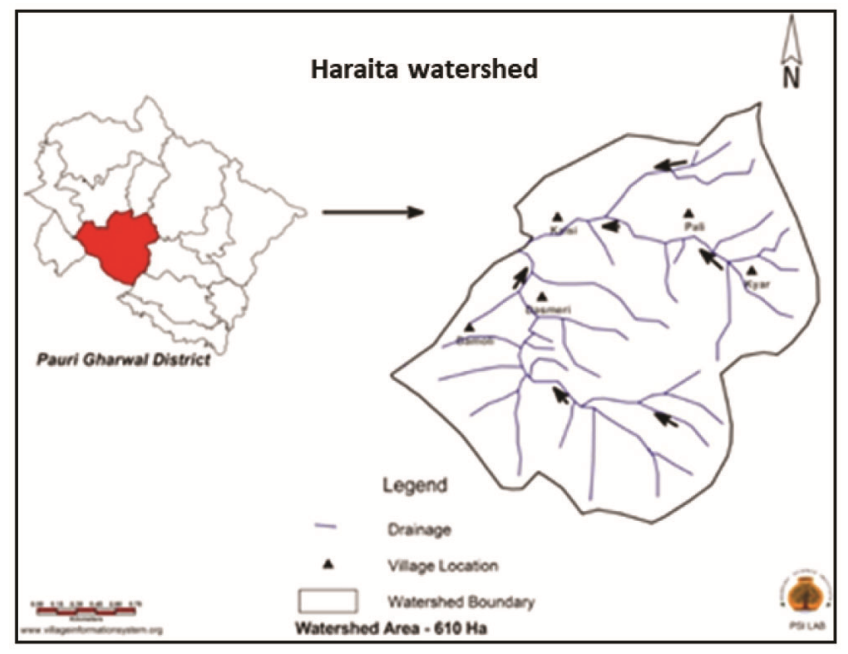

Figure 1. Image of Haraita watershed, Pauri Garhwal, Uttarakhand, India. 
Table 1. Spring location in Haraita watershed, Pauri Garhwal, Uttarakhand, India

\begin{tabular}{lccccc}
\hline Spring & Latitude & Longitude & Elevation $(\mathrm{m})$ & Slope (\%) & Land use \\
\hline Kasti Gadera Malla & $29^{\circ} 57^{\prime} 06^{\prime \prime} \mathrm{N}$ & $78^{\circ} 35^{\prime} 03^{\prime \prime} \mathrm{E}$ & 1530 & $20-30$ & Barren agricultural land \\
Nauli Dhara & $29^{\circ} 57^{\prime} 09^{\prime \prime} \mathrm{N}$ & $78^{\circ} 34^{\prime} 53^{\prime \prime} \mathrm{E}$ & 1448 & $20-30$ & Barren agricultural land \\
Bichola Pani & $29^{\circ} 57^{\prime} 09^{\prime \prime} \mathrm{N}$ & $78^{\circ} 34^{\prime} 51^{\prime \prime} \mathrm{E}$ & 1423 & $20-30$ & Barren agricultural land \\
Jethuna Tok & $29^{\circ} 57^{\prime} 08^{\prime \prime} \mathrm{N}$ & $78^{\circ} 34^{\prime} 50^{\prime \prime} \mathrm{E}$ & 1412 & $20-30$ & Barren agricultural land \\
\hline
\end{tabular}

Table 2. Spring location in Shiv Gadera watershed, Almora, Uttarakhand

\begin{tabular}{lccccl}
\hline Spring & Latitude & Longitude & Elevation $(\mathrm{m})$ & Slope (\%) & Land use \\
\hline Malli Naula & $29^{\circ} 45^{\prime} 20^{\prime \prime} \mathrm{N}$ & $79^{\circ} 33^{\prime} 26^{\prime \prime} \mathrm{E}$ & 1560 & $20-30$ & Settlement \\
Shiv Dhara & $29^{\circ} 47^{\prime} 20^{\prime \prime} \mathrm{N}$ & $79^{\circ} 33^{\prime} 34^{\prime \prime} \mathrm{E}$ & 1553 & $20-30$ & Settlement and forest \\
Talli Naula & $29^{\circ} 47^{\prime} 21^{\prime \prime} \mathrm{N}$ & $79^{\circ} 33^{\prime} 34^{\prime \prime} \mathrm{E}$ & 1565 & $20-30$ & Settlement and forest \\
\hline
\end{tabular}

Table 3. Land cover class and area of Haraita watershed

\begin{tabular}{lcc}
\hline Class & Area (ha) & Percentage cover (\%) \\
\hline Dense forest & 217.6 & 5.4 \\
Open forest & 1613.58 & 40.0 \\
Agriculture & 2202.12 & 54.5 \\
Settlements & 2.15 & 0.1 \\
\hline
\end{tabular}

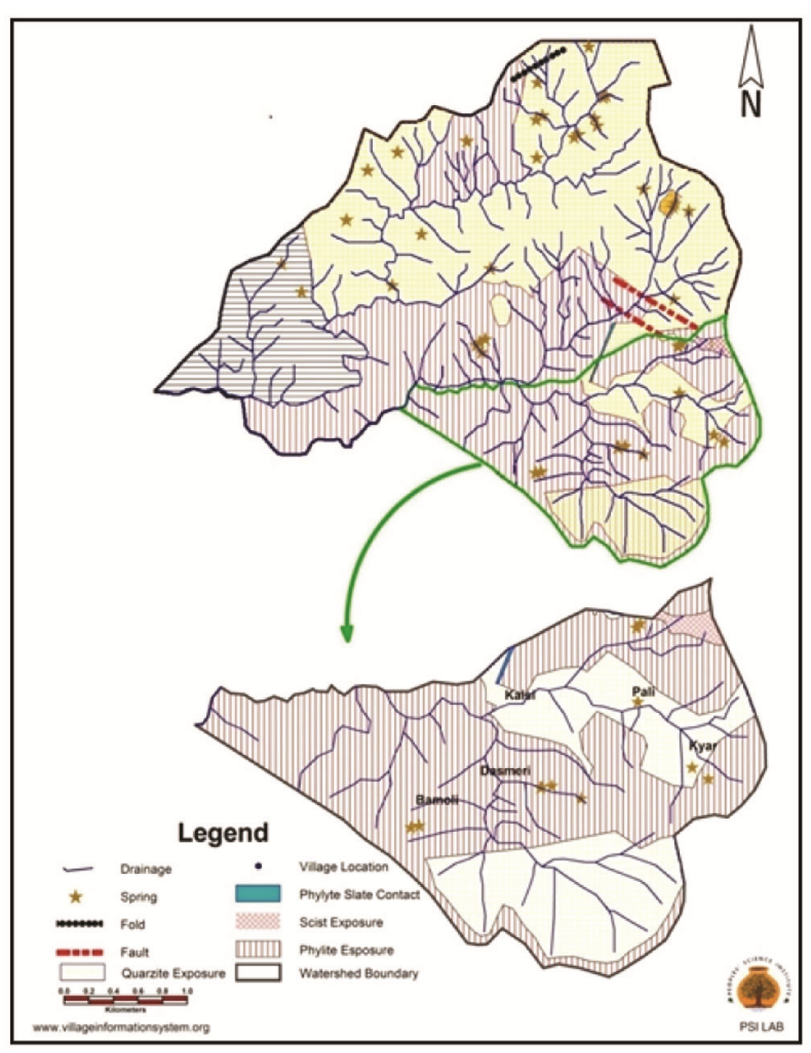

Figure 2. Stream network and geology of Haraita watershed, Pauri Garhwal, Uttarakhand, India.

\section{Land-use and land-cover assessment}

Land-use and land-cover (LULC) patterns significantly impact the functioning of montane ecosystems and directly impact plant and habitat diversity, climatic trends, hydrological systems, soil quality and demography. LULC changes impact assessment on water resources, run-off, infiltration, soil and water quality, and flood management is necessary for hydrological monitoring and modelling studies. The present study endeavours to understand the nature and intensity of LULC in the selected watersheds towards assessing their impact on water balance, which will aid in formulating a comprehensive water budget for the Himalayan communities. At the same time, understanding the influence of anthropogenic stresses on the local hydrology and ultimately devising a practical land and water conservation blueprint for water security in the Himalayan ecosystems is required. The present land use pattern of Haraita watershed and Shiv Gadera watershed is categorized as dense forests (217.6 ha), open forests (1613.58 ha), agriculture (2202.12) and settlements (2.15 ha) (Tables 3 and 4$)$.

The total land under the Haraita watershed is 4035.45 ha. Only $5.4 \%$ of the area is dense forests, about $40 \%$ is open forests, agriculture land accounts for $54.5 \%$ of total area and $0.1 \%$ is under settlements (Figure 5).

For the Shiv Gadera watershed, a sloping topography is the common characteristic of the entire land. The total area under the Shiv Gadera watershed is 2394.36 ha. The total dense forest land is 410.15 ha and open forest land is $1501.2 \mathrm{ha}$. Agricultural land is $17.6 \%$ of total area (421.48 ha) and barren land is $0.7 \%$ (17.85 ha). 43.68 ha land is under settlement, accounting for $1.8 \%$ (Figure 6).

\section{Seasonal domestic water consumption patterns at Pauri-Garhwal and Almora sites}

Figures 7 and 8 show that the average household water consumption is below the norm of 70 lpcd. The value in the villages is relatively low, since most of the households utilize water for washing clothes, utensils, etc., at the source itself. The struggle of the people (mostly 


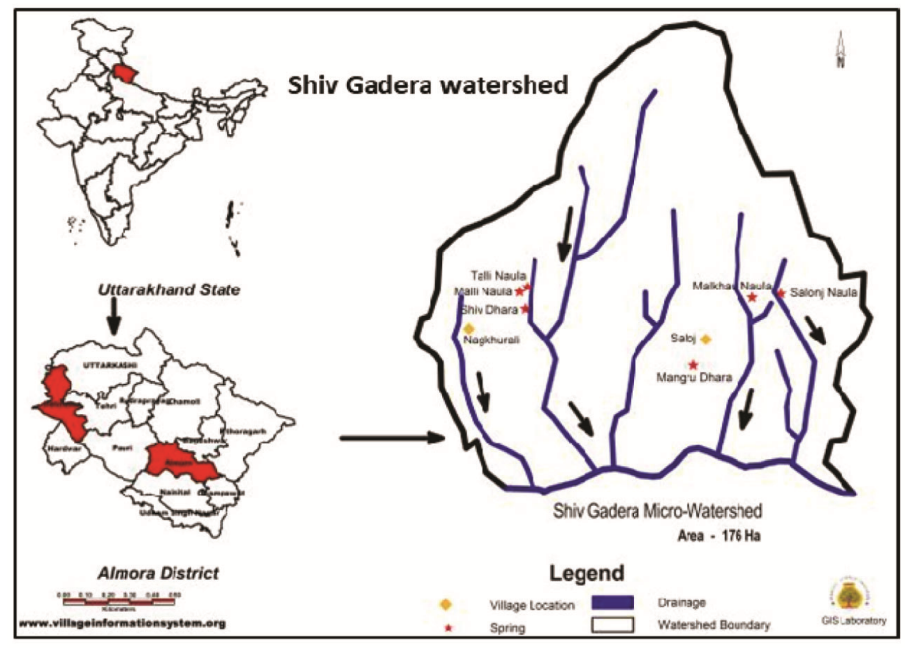

Figure 3. Image of Shiv Gadera watershed, Almora, Uttarakhand.

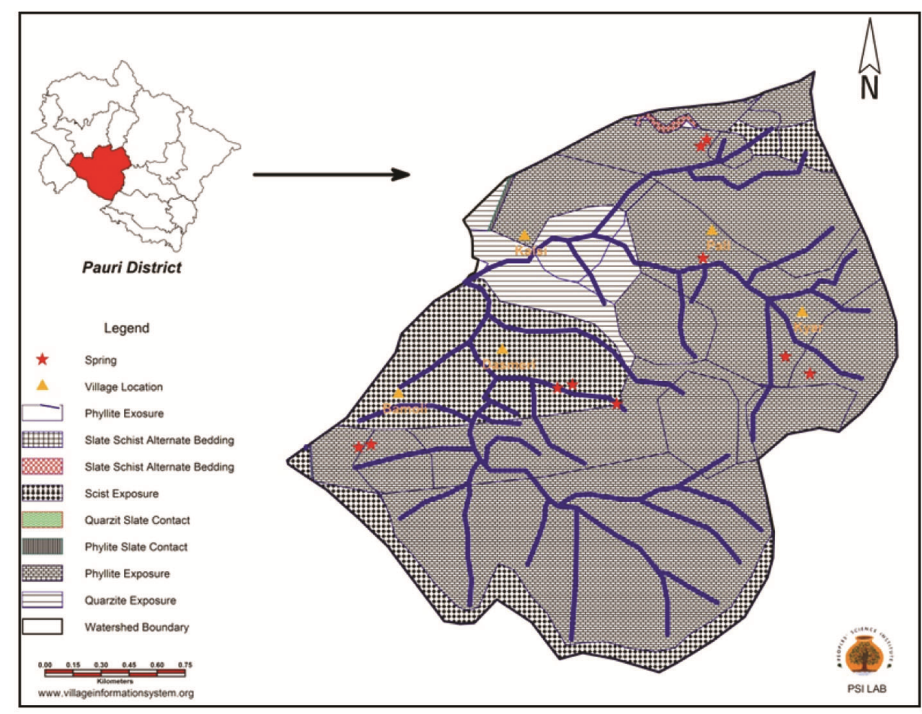

Figure 4. Stream network and geology of Shiv Gadera watershed, Almora, Uttarakhand, India.

Table 4. Land cover class and area of Shiv Gadera watershed

\begin{tabular}{lrc}
\hline Class & Area (ha) & Percentage cover (\%) \\
\hline Dense forest & 410.15 & 17.1 \\
Open forest & 1501.20 & 62.8 \\
Agriculture & 421.48 & 17.6 \\
Barren/fallow land & 17.85 & 0.7 \\
Settlements & 43.68 & 1.8 \\
\hline
\end{tabular}

women) increases during the summer months when water reduces in the sources.

\section{Monitoring techniques adopted and data expected}

Discharge measurements: Flumes cater to streams of rapidly changing stage and unanticipated stream-level rises. Hence, to monitor discharge in critical springs, $\mathrm{H}$-flumes are installed, and to assess run-off and streamflow, Parshall flumes have been used. These are devices calibrated for the measurement of water flows in channels. Parshall flumes are calibrated against a piezometric head $H_{a}$ at convergence and $H_{b}$ at the downstream throat.

For free flow

$$
Q=K H_{a}^{n}
$$

where $Q$ is the flow rate $\left(\mathrm{m}^{3} \mathrm{~s}^{-1}\right), K$ the flume discharge constant that depends on flume size, $H_{a}$ and $H_{b}$ are the depth of water at the upstream and downstream respectively in metres, and $n$ is the discharge exponents that depend on the flume size.

For submerged flow

$$
Q=\frac{C_{s} W\left(H_{a}-H_{b}\right)^{n_{f}}}{\left[-\log _{10} S+0.0044\right]^{n_{s}}},
$$


where $W$ is the throat width, $n_{f}$ the free-flow exponent, $n_{s}$ the submerged-flow exponent, $C_{s}$ the submergence constant and $S$ is the submergence ratio $\left(H_{a} / H_{b}\right)$.

On the other hand, the H-flume with a V-type control can provide a wide opening at high flows, reducing backwater effects, and a reduced opening at low flows, which maintains the sensitivity of the structure. The H-flume operates by accelerating slow, sub-critical flow $(F r<1)$ to a supercritical state $(F r>1)$ by restricting the flow on its passage through it.

$$
\log Q=A+B \log H_{a}+C\left(\log H_{a}\right)^{2},
$$

where $H_{a}$ is the upstream head, and $A, B, C$ are constants. The error expected is less than $3 \%$.

Evapotranspiration: The efficient quantification of actual evapotranspiration is fundamental to the formulation of a water budget for water resources management. The water budget is composed of a high share of actual evapotranspiration $\left(\mathrm{ET}_{a}\right)$; about $64 \%$ of precipitation input on landmass returns to the atmosphere ${ }^{6}$. Present studies require hydrological models for assessing the impacts of anthropogenic stresses on Himalayan hydrologic systems. Accurate quantification of spatial and temporal water fluxes in, out, and within the Himalayan systems is a prerequisite for an effective hydrological model. The difference between precipitation and $\mathrm{ET}_{a}$ gives the available water for human use, environmental flows, and aquifer recharge. Hence better estimation is essential to minimize

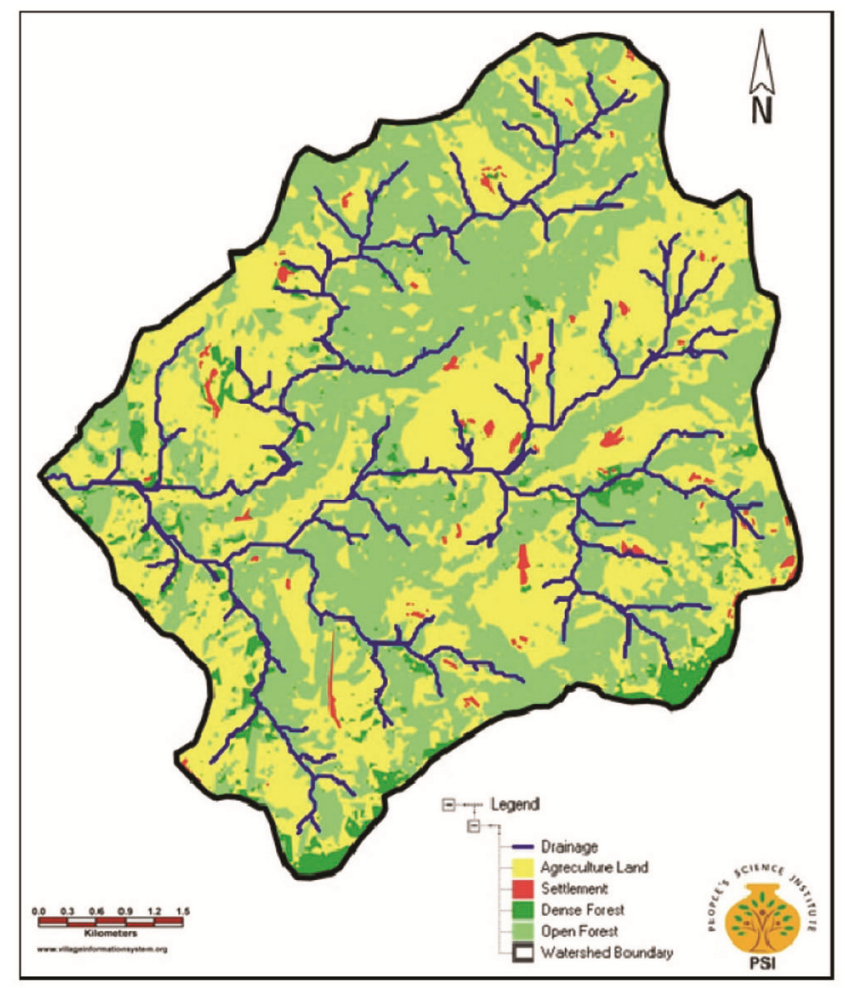

Figure 5. Land cover map of Haraita watershed. relative error amplification that comes with available water quantification.

The Penman-Montieth method is suitable in studies that require ambient air temperature, solar radiation, wind speed, relative humidity $(\mathrm{RH})$ as input values. The generalized form of the Penman equation is called the Penman-Montieth (PM) evapotranspiration ${ }^{7,8}$.

The PM equation is latent energy

$$
\lambda \mathrm{ET}=\frac{\Delta\left(R_{\text {net }}-H_{\mathrm{f}}\right)+\rho_{\mathrm{a}} c_{\mathrm{a}}\left(e_{\mathrm{s}}-e\right) / r_{\mathrm{a}}}{\Delta+\gamma\left(1+\frac{r_{\mathrm{s}}}{r_{\mathrm{a}}}\right)},
$$

where $\Delta$ is the vapour pressure saturation slope $\left(\mathrm{kPa}^{\circ} \mathrm{C}^{-1}\right)$, $R_{\text {net }}$ the net solar radiation $\left(\mathrm{MJm}^{-2} \mathrm{~d}^{-1}\right), H_{\mathrm{f}}$ the soil surface heat flux, $\rho_{\mathrm{a}}$ the density of air, $c_{\mathrm{a}}$ the specific heat of air,

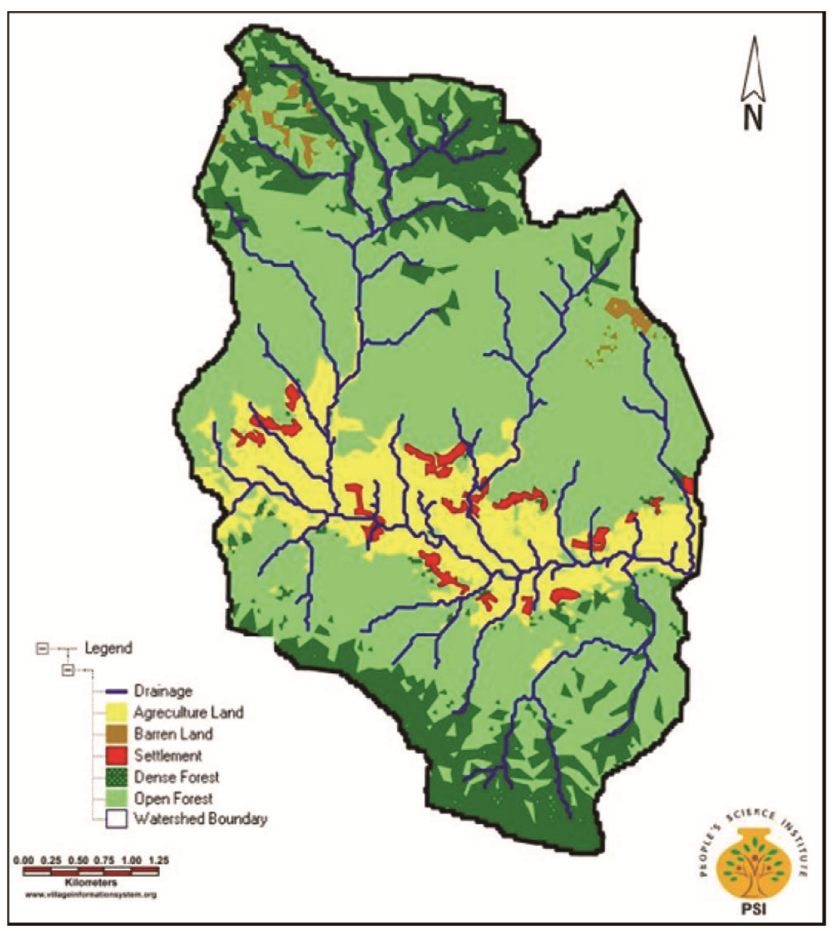

Figure 6. Land cover map of Shiv Gadera watershed.

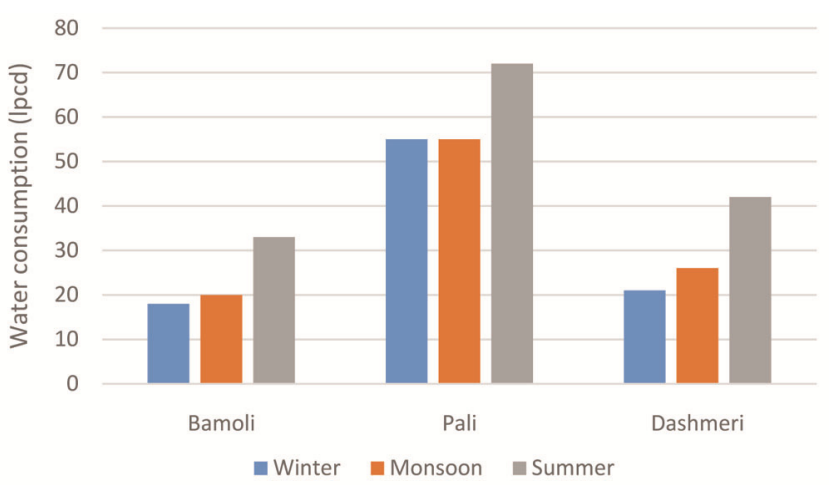

Figure 7. Seasonal water consumption (lpcd) in Haraita watershed. 
$e_{\mathrm{s}}$ and $e$ the saturated and actual vapour pressures respectively, $r_{\mathrm{s}}$ and $r_{\mathrm{a}}$ bulk surface and aerodynamic resistance respectively, and $\gamma$ is a psychometric constant $\left(\mathrm{kPa}^{\circ} \mathrm{C}^{-1}\right)$. $R_{\text {net }}$ and $H_{\mathrm{f}}$ can be estimated from incoming solar radiations as described by Walter et al. ${ }^{9}$. Aerodynamic resistance can be estimated by assuming neutral condition from Monin-Obukhov similarity ${ }^{10}$

$$
r_{\mathrm{a}}=\frac{\ln \left[\frac{(x-d)}{x_{0}}\right] \ln \left[\frac{(x-d)}{x_{0 v}}\right]}{k^{2} u},
$$

where $x(\mathrm{~m})$ is the height of the wind sensor, $d(\mathrm{~m})$ the displacement height, $x_{0}(\mathrm{~m})$ the momentum roughness height, $x_{0 v}(\mathrm{~m})$ the water vapour roughness height, $k$ (0.41) the Von-Karman's constant and $u\left(\mathrm{~ms}^{-1}\right)$ is the lateral wind speed. According to Brutsaert ${ }^{11}, d$ is equal to $67 \%$ of vegetation height $\left(x_{v \mathrm{eg}}\right), x_{0}$ may be estimated as $0.1 x_{v \mathrm{eg}}$ (ref. 12) and $x_{0 v}$ can be approximated as $0.1 x_{0}$ (ref. 13).

The PM reference evapotranspiration $\left(\mathrm{ET}_{0}\right)$ is defined by the Food and Agricultural Organization, Rome, as a standard, hypothetical $12 \mathrm{~cm}$ grass reference crop under amply watered conditions ${ }^{14}$ with a constant surface resistance of $70 \mathrm{sm}^{-1}$ (ref. 13) and a ratio of effective to incident solar radiation of 0.23 .

$$
\mathrm{ET}_{0}=\frac{0.408 \Delta\left(R_{\text {net }}-H_{\mathrm{f}}\right)+\gamma \frac{C_{\mathrm{n}}}{T+273} u_{2}\left(e_{\mathrm{s}}-e\right)}{\Delta+\gamma\left(1+C_{\mathrm{d}} u_{2}\right)},
$$

where $T$ is the mean daily air temperature at $1.5-2.5 \mathrm{~m}$ height above surface $\left({ }^{\circ} \mathrm{C}\right), u_{2}$ is the mean lateral wind speed at $2 \mathrm{~m}$ above the surface, $e_{\mathrm{s}}$ and $e$ are saturation and actual vapour pressure at $1.5-2.5 \mathrm{~m}$ height respectively $(\mathrm{kPa}), C_{\mathrm{n}}$ and $C_{\mathrm{d}}$ are the numerator and denominator constants respectively, for reference types (taken as 900 and 0.34 respectively, for daily time-steps).

\section{Field campaigns and experimental set-up}

Field campaigns were conducted initially to inventorize the springs in the selected project districts in Uttarakhand. The selection of sites for instrumentation of both springs and streams was done after a reconnaissance survey. Several factors were considered, such as the criticality of springs in terms of declining discharge and water quality, local community dependence and support, flatter gradients not susceptible to changes, bedrock, sediment deposition, ease of accessibility and installation, and instrument safety. The selection of sites representing different land usage and coverage was also taken into account as the data's diversity will help in proper assessment of the Himalayan hydrology and increase the relevance of the pilot studies. The springs selected for the initial phase of instrumentation are called dharas in the local language. For gauging the stage and discharge, they were instrumented with HS-flumes and Odyssey ${ }^{\circledR}$ capacitance water level probes (Dataflow Systems Limited, New Zealand). Three springs in Dasmeri watershed (PS1, PS2, PS3), Pauri Garhwal and one spring in Shiv Gadera watershed (AS1), Almora were installed with $0.6 \mathrm{ft}$ HSflume using masonry and leak-proofing the area for efficiently channelizing the flow. A stilling well with a small opening at the base was also installed adjacent to the flow channel. The sensor element was lowered into the stilling well, and the logger encased in a cylindrical casing was secured in a metal box to protect it from extreme weather, wild animals, and random vandalism. The selected locations for the stream gauges, one each in both the watersheds were installed with 12 inch Parshall flumes complemented with stilling wells and capacitance-based water-level loggers. Both these watersheds were equipped with an automatic weather station (AWS). They can measure precipitation, wind speed and direction, solar radiation, atmospheric pressure, and relative humidity. The AWS installation sites must be free from any canopy, electricity distribution lines and must be in an open space not to obstruct wind, rainfall and sunlight. The preconfigured set of sensors was mounted on a cross arm and attached to a standard pole mast. The mountings were levelled, and the stands are grouted in concrete to firmly secure them to the base. The data-logger was also mounted on the pole mast and secured in a metal safety box.

\section{Dedicated long-term monitoring observatory}

Intensive monitoring started in May 2018 in the Haraita watershed, whereas for the Shiv Gadera watershed, it began in June 2018. The details of instrumentation are mentioned in Table 5. Capacitance-based water-level probes were placed in HS and Parshall flumes. Waterstage data in the stilling wells at the flumes were converted into volumetric flow rate $\left(\mathrm{m}^{3} / \mathrm{s}\right)$ using the governing discharge equations (eqs (1)-(3)). The AWS (METER

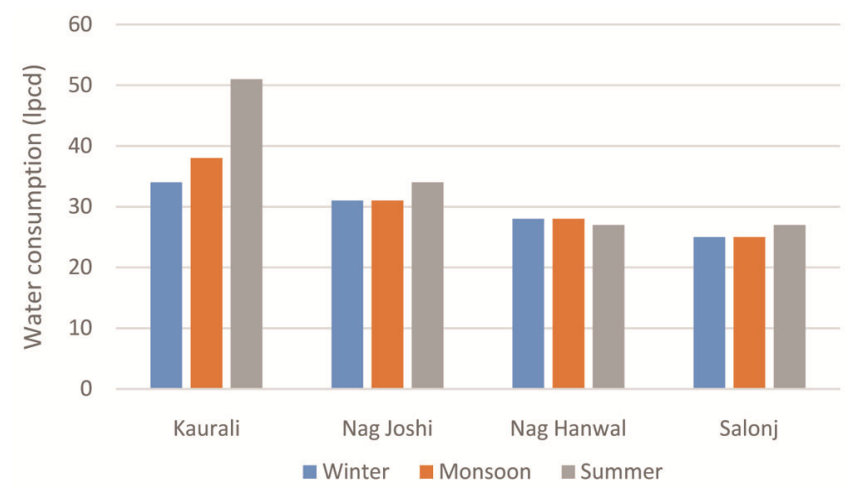

Figure 8. Seasonal water consumption (lpcd) in Shiv Gadera watershed 
Table 5. Details of site instrumentation

\begin{tabular}{|c|c|c|c|c|}
\hline Site & Instrument & Installation date & Instrument details & Data measurements \\
\hline \multirow[t]{4}{*}{ Haraita watershed } & \multirow[t]{4}{*}{ Automatic weather station } & \multirow[t]{4}{*}{27 May 2018} & Davis cup anemometer & Wind speed and direction \\
\hline & & & ECRN 50 rain gauge & Precipitation \\
\hline & & & ATMOS 14 & $\begin{array}{l}\text { Air temperature, } \\
\text { humidity and vapour } \\
\text { pressure }\end{array}$ \\
\hline & & & PYR pyranometer & Solar radiation flux \\
\hline Nauli Dhara (Spring PS1) & Water Level Logger & 27 June 2018 & \multirow{4}{*}{$\begin{array}{l}\text { Odyssey capacitance- } \\
\text { based water-level } \\
\text { sensor element }\end{array}$} & \multirow[t]{4}{*}{ Stage } \\
\hline Bichola Pani (Spring PS2) & Water Level Logger & 27 June 2018 & & \\
\hline Jethuna Tok (Spring PS3) & Water Level Logger & 27 June 2018 & & \\
\hline Daulik Ukhlyan (Stream P_St) & Water Level Logger & 27 June 2018 & & \\
\hline Nauli Dhara & HS-flume & 27 June 2018 & $0.6 \mathrm{ft}$ & Discharge \\
\hline Bichola Pani & HS-flume & 27 June 2018 & $0.6 \mathrm{ft}$ & \\
\hline Jethuna Tok & HS-flume & 27 June 2018 & $0.6 \mathrm{ft}$ & \\
\hline Daulik Ukhlyan & Parshall flume & 27 June 2018 & 12 inch & \\
\hline \multirow[t]{5}{*}{ Kausani village } & \multirow[t]{4}{*}{ Automatic weather station } & \multirow[t]{4}{*}{2 July 2018} & Davis cup anemometer & Wind speed and direction \\
\hline & & & ECRN 50 rain gauge & Precipitation \\
\hline & & & ATMOS 14 & $\begin{array}{l}\text { Air temperature, } \\
\text { humidity and vapour } \\
\text { pressure }\end{array}$ \\
\hline & & & PYR pyranometer & Solar radiation flux \\
\hline & Non-recording rain gauge & 2 July 2018 & $\begin{array}{l}\text { Ordinary rain gauge with } \\
\text { jar }\end{array}$ & Rainfall \\
\hline Shiv Dhara (Spring AS1) & Water Level Logger & 23 June 2018 & \multirow{2}{*}{$\begin{array}{l}\text { Odyssey capacitance- } \\
\text { based water-level } \\
\text { sensor element }\end{array}$} & \multirow[t]{2}{*}{ Stage } \\
\hline Shiv Gadera (Stream A_st) & Water Level Logger & 23 June 2018 & & \\
\hline Shiv Dhara & HS-flume & 23 June 2018 & $0.6 \mathrm{ft}$ & \multirow[t]{2}{*}{ Discharge } \\
\hline Shiv Gadera & Parshall flume & 23 June 2018 & 12 inch & \\
\hline
\end{tabular}

group, USA) recorded the following hydrometeorological variables:

(a) Rainfall using a single spoon tipping bucket rain gauge of one tip resolution at $5 \mathrm{ml} /$ tip measuring $1 \mathrm{~mm}$ rainfall with each tip.

(b) Wind speed and direction using a Davis cup anemometer; wind speed, and direction accuracy of $\pm 5 \%$ and $7^{\circ}$, and wind speed and direction resolution of $1 \mathrm{mph}$ and $1^{\circ}$ respectively. The threshold was at three mph.

(c) Air temperature, RH, barometric pressure, and vapour pressure using a combined sensor in ATMOS 14. A microprocessor embedded within calculates vapour pressure from $\mathrm{RH}$ and temperature measurements. It utilizes a capacitance-type RH sensor chip to measure $\mathrm{RH}$ and temperature of the surrounding air.

(d) Solar radiation using a pyranometer, which measures the solar radiation flux density from a hemispherical field view of $180^{\circ}$. Calibration for an operating temperature at $-40^{\circ} \mathrm{C}$ to $+60^{\circ} \mathrm{C}$ was done at $5 \mathrm{Wm}^{-2}$.

\section{Results}

Figure 9 shows the first set of processed data after instrumentation of the selected critical springs and the streams and Figure 10 displays the installations at each watershed. Based on the first set of hydrological data we can infer that geology plays a crucial role in aquifer recharge. The geology of Haraita (Pauri) is more complex. It has presence of a well-developed fracture system and exhibits variable flow dynamics. Therefore, recharge interventions as carried out in Shiv Gadera (Almora) will not produce similar results in Haraita. The rate of aquifer recharge will be slower in Haraita suggesting that more inputs and intense planning will be required for groundwater recharge interventions. The stage data from the water-level loggers was used and flow rates were computed, which are plotted against daily rainfall data collected by AWS. The discharge versus rainfall data are shown in Figure $9 a$ and $c$ for springs, Figure $9 b$ and $c$ for the stream gauge.

\section{Discussion}

The discharge data plotted against rainfall give us important information on the various controls on spring discharges and stream flow. With the commencement of the monsoon, there is an increase in the flows. Hydrological response to precipitation events can be seen in all the gauges. These trends in the first rainy season will help formulate a reference dataset for baseline studies which will eventually prove decisive in devising springshed treatment and intervention plans.

- The spring hydrographs of Haraita watershed in Figure $9 c$ show an increase in discharge succeeding 

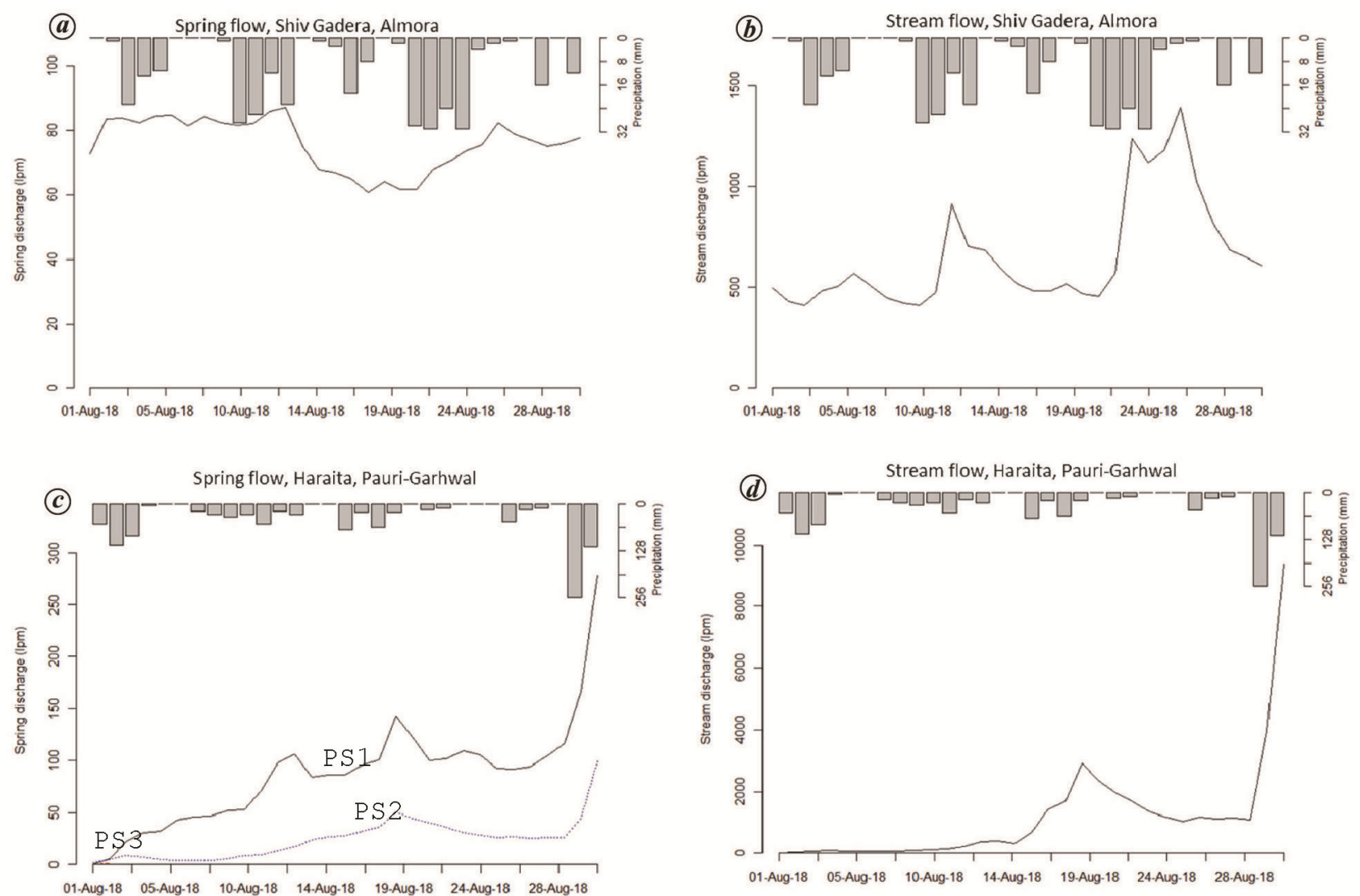

Figure 9. Spring and stream hydrographs of selected watersheds: $(\boldsymbol{a})$ and $(\boldsymbol{b})$ Shiv Gadera watershed and $(\boldsymbol{c})$ and $(\boldsymbol{d})$ Haraita watershed (PS1, PS2 and PS3).

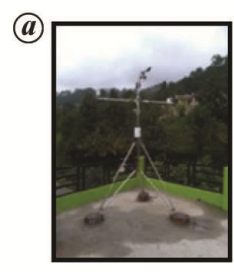

(g)

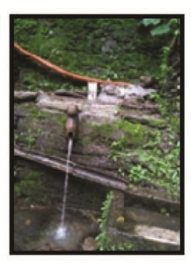

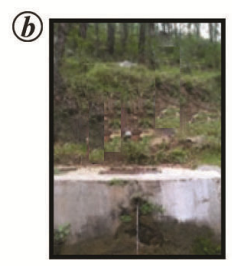

(h)

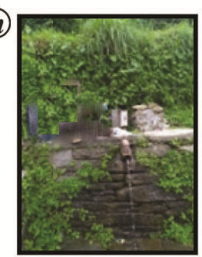

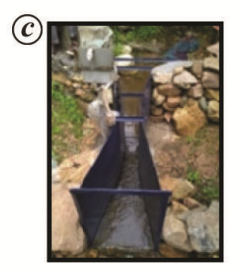

(i)

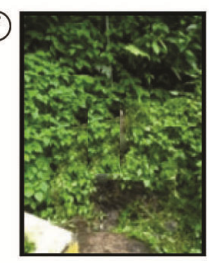

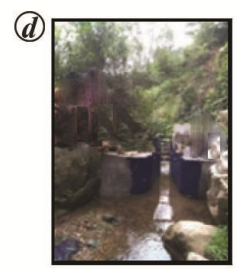

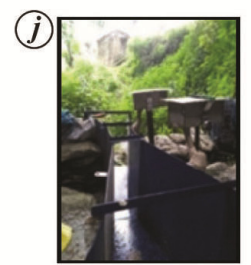

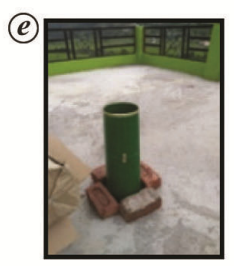

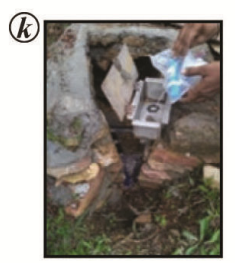

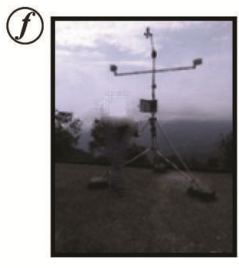

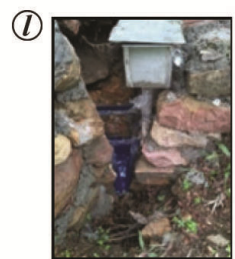

Figure 10. $\boldsymbol{a}$, AWS at Almora; $\boldsymbol{b}$, spring gauge at Shiv Gadera watershed; $\boldsymbol{c}, \boldsymbol{d}$, stream gauge at Shiv Gadera watershed; $\boldsymbol{e}$, ordinary rain gauge at Almora; $\boldsymbol{f}$, AWS at Pauri-Garhwal; $\boldsymbol{g}-\boldsymbol{i}$, spring gauges in Dasmeri watershed; $\boldsymbol{j}$, stream gauge at Haraita watershed; $\boldsymbol{k}, \boldsymbol{l}$, data-logger enclosure (lockable metal box).

rainfall events after August on 1, 2 and 3 of the month.

- The spring hydrographs of Haraita are expected to show significant recession after the monsoon season is over and data analysed for the rainy season. The discharge in the springs is a function of aquifer recharge; so it can be expected to increase in the last phase of the rainy season.

- The discharge in the spring of Shiv Gadera watershed (Figure $9 a$ ) shows a consistent flow of 60-80 LPM for the better part of August, an increase in the flows can be attributed to the rainfall events from 11 till 14 and 21 till 24 of the month. The discharge may be expected to peak in August and recess after the rainy season is over.

- The stream-flow data of the Shiv Gadera watershed (Figure $9 b$ ) show several isolated peaks, with maximum peak flow being 1392.7 LPM on 26 August. This may be attributed to the rainfall events from 21 till 25 August. During installation, there was no flow in the CURRENT SCIENCE, VOL. 120, NO. 5, 10 MARCH 2021 
stream of Haraita watershed, Pauri; but as soon as rainfall events occurred, a gradual increase in the flows can be seen.

\section{Conclusion}

This article provides an overview of the pilot springshed observatory at Haraita and Shiv Gadera as a part of the National Mission on Himalayan Studies (NMHS) endeavour towards springshed management in the Indian Himalayas, accompanied by the first set of high resolution dataset for an integrated research on hydrological functioning of springsheds. The pilot observatory lays the platform for research addressing complex hydro-geological problems by merging expertise from disciplines like hydrology, geology, environmental sciences and sociology. Although the results are in the initial phase and the observatory infrastructures are newly setup, the pilot research demonstrates how interdisciplinary research conducted can provide comprehensive, rich datasets that shall allow new insights into springshed hydrological processes. Besides, it facilitates both the development of new approaches in monitoring and modelling to address specific environmental questions as well as new measurement techniques into springshed research in the Himalayas. Monitoring observatories have started to provide the urgently required high-resolution long-term series of hydrological data, which can be employed to set up and run models for a better understanding of springshed functioning. Such approaches will, in turn, support the ultimate goal of assessing water security and devise ways for springshed management in the Indian Himalayas.

The hydrometeorological data acquired from the AWSs and the evapotranspiration computed can establish relationships between the various meteorological fluxes concerning precipitation intensity and streamflow controls, aiding in the formulation of research questions about: Understanding responses of rainfall and runoff characteristics on Himalayan aquifer recharge; the influence of vegetation cover on aquifer recharge through evapotranspiration demands on base flow pathways; the effect of diurnal flow patterns on aquifer transmissivity and storage during lean flows.

\section{Future viewpoint}

IHR has conspicuous climate variability, erratic precipitation patterns, varied LULC, differential soil/water quality, and a complex network of aquifers feeding montane springs. Understanding the predominant hydrologic processes with high accuracy and reliable data is a prerequisite to watershed modelling, and knowledge dissemination to stakeholders and decision-makers. These dedicated monitoring programmes at Pauri and Almora districts of Uttarakhand will provide relevant information at finer resolutions, which will confer adequate ecological understanding at springshed level towards nationwide policy-making and capacity-building in Himalayan springshed management.

1. Bales, R. C., Molotch, N. P., Painter, T. H., Dettinger, M. D., Rice, R., and Dozier, J., Mountain hydrology of the western United States. Water Resour. Res., 2006, 42.

2. Barnett, T. P., Adam, J. C. and Lettenmaier, D. P., Potential impacts of a warming climate on water availability in snow and dominated regions. Nature, 2005, 438, 303-309.

3. Schimel, D., Kittel, T. G. F., Running, S., Monson, R., Turnipseed, A. and Anderson, D., Carbon sequestration studied in western U.S. mountains. EOS, Trans. Am. Geophys. Union, 2002, 83, 445-449.

4. Kumar, V. and Sen, S., Analysis of spring discharge in the Lesser Himalayas: a case study of Mathamali spring, Aglar watershed, Uttarakhand BT. In Water Resources Management (eds Singh, V. P., Yadav, S. and Yadava, R. N.), Springer Singapore, Singapore, 2018, pp. 321-338.

5. Kumar, V. and Sen, S., Evaluation of spring discharge dynamics using recession curve analysis: a case study in data-scarce region, Lesser Himalayas, India. Sustain. Water Resour. Manage., 2018, 4, 539-557.

6. Baumgartner, A. and Reichel, E., The World Water Balance: Mean Annual Global, Continental and Maritime Precipitation and Run-off, Elsevier, 1975.

7. Penman, H. L. and Keen, B. A., Natural evaporation from open water, bare soil and grass. Proc. R. Soc. London. Ser. A. Math. Phys. Sci., 1948, 193, 120-145.

8. Monteith, J. L., Evaporation and environment. Symp. Soc. Exp. Biol., 1965, 19, 205-234.

9. Walter, I. A. et al., ASCE's standardized reference evapotranspiration equation. Watershed Manage. Oper. Manage. 2000, 4 January 2021, pp. 1-11.

10. Sumner, D. M. and Jacobs, J. M., Utility of Penman-Monteith, Priestley-Taylor, reference evapotranspiration, and pan evaporation methods to estimate pasture evapotranspiration. J. Hydrol., 2005, 308, 81-104.

11. Brutsaert, W., Evaporation into the Atmosphere: Theory, History, and Applications, Springer, Dordrecht, 1982.

12. Dingman, S. L., Physical Hydrology, Prentice Hall, Upper Saddle River, NJ, USA, 2002.

13. Jensen, M. and Allen, R., Evaporation, Evapotranspiration, and Irrigation Water Requirements Evaporation, Evapotranspiration, Irrig. Water Requir, 2016.

14. Allan, R., Pereira, L. and Smith, M., Crop evapotranspirationGuidelines for computing crop water requirements. FAO Irrigation and drainage paper $56,1998$.

ACKNOWLEDGMENTS. We thank the National Mission on Himalayan Studies, Almora, Ministry of Environment, Forest and Climate Change, Government of India, for financial support. Thanks are also due to the G.B. Pant National Institute of Himalayan Environment and Sustainable Development for research cooperation and chairing progress review meets. We also thank Dr Anil Gautam (PSI, Dehradun) for support and Ravi Meena, Shanu Khan, Dharmender Singh Panwar, and Maya Verma and her women's group for help in field surveys and maintenance operations.

doi: $10.18520 /$ cs/v120/i5/791-799 